\title{
Experimental Study of Photocatalytic Effect on Paver Blocks
}

\author{
P. Jeganmurugan ${ }^{1 a}$, A. Sree Rameswari ${ }^{2 b}$, N. Anuja ${ }^{3 c}$ and V. Sherin ${ }^{4 d}$ \\ ${ }^{1}$ Assistant Professor, Department of Civil Engineering, Karpagam College of Engineering, \\ Coimbatore, Tamil Nadu, India \\ ${ }^{2}$ Assistant Professor, Department of Civil Engineering, PSNA College of Engineering and \\ Technology, Dindigul, Tamil Nadu, India \\ ${ }^{3}$ Assistant Professor, Department of Civil Engineering, Mepco Schlenk Engineering College, \\ Sivakasi, Tamil Nadu, India \\ ${ }^{4}$ Assistant Professor, Department of Civil Engineering, KCG College of Technology, Chennai, \\ Tamil Nadu, India \\ ajeganmurugan1086@gmail.com*, bsreerameswari@gmail.com, canu_priya1031@yahoo.com, \\ dvsherin2911@gmail.com
}

Keywords: Paver Block, Titanium Dioxide, UV Radiation, Photocatalytic Effect

\begin{abstract}
The increasing population and massive use of vehicles caused the atmospheric air to be more polluted and its effect on human beings is increasing all over the world and hence the introduction of pollution controlling paver blocks can helps in absorbing the vehicles pollution. From this paver block the venture is being made to reduce the pollution using titanium oxide and other chemicals by photocatalytic method. The titanium dioxide absorbs pollutions by the reaction with UV radiation titanium dioxide power is applied in three different methods on the paver blocks in order to find the most effective pollution absorbing capacity of the paver blocks.
\end{abstract}

\section{Introduction}

In today's world the three major things we are focusing is industrialization, globalization and modernization. Due to above three the $21^{\text {st }}$ century is moving towards devastation. The green lawn areas are reducing consecutively and its being one of the causes of global warming. But it is not too dangerous. However in future this problems may create big impact, therefore proper initiation need to be taken from today. The most common problems in all metropolitan cities are increasing population, industrial pollution, traffic jams, road accidents etc., This are some of the highlighted issues which are creating pollutions on urban cities. The major cause for air pollution is created by vehicles. To avoid this problem the road system need to contribute in the way of absorbing pollutant gases emits by the vehicle directly to the atmosphere.

To achieve this idea in successful manner by, adding chemicals to the paver blocks in order to absorb pollutant gases and reducing air pollution in atmosphere. In this project, we are using titanium dioxide $\left(\mathrm{TiO}_{2}\right)$, as a photo catalyst. Titanium is a naturally occurring oxide compounds, it can decompose pollutant gases present in atmosphere with the presence of ultra violet radiation. Adding $\mathrm{TiO}_{2}$ to the pavement by various methods, we can obtain reduction in the level of emission of pollutant gases in atmosphere. When $\mathrm{TiO}_{2}$ is added to paver blocks, the air will get purified on sunny days due to photocatalytic process. By this innovative idea, the project members aim to identify the effective method of adding $\mathrm{TiO}_{2}$ to the paver blocks to produce an eco-friendly road environment. 


\section{Materials used}

Cement (OPC 53 grade)

Ultratech cement of 53 grades (Ordinary Portland cement) was used in this project. The OPC 53 grade cement was tested by IS code of 12269-1987 \& 4031-1988. The properties of OPC 53 grade cement were mentioned in Table 1.

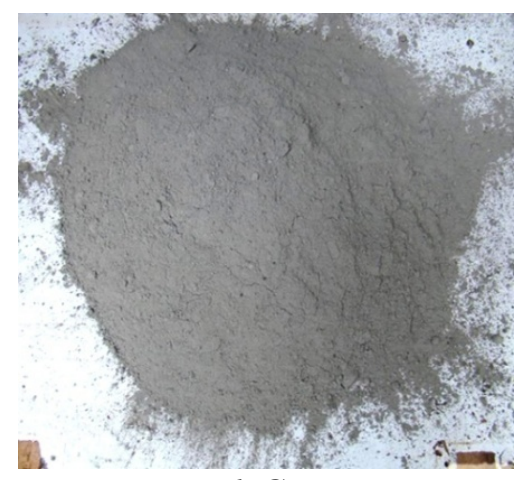

Figure 1 Cement

Table 1 Properties of (OPC 53 Grade) Cement

\begin{tabular}{|c|l|c|}
\hline S.No & \multicolumn{1}{|c|}{ Property } & Result \\
\hline 1. & Fineness of cement & $96 \%$ \\
\hline 2. & Relative density & 3.16 \\
\hline 3. & Standard Consistency & $30 \%$ \\
\hline 4. & Initial setting time & $33 \mathrm{~min}$ \\
\hline
\end{tabular}

Fine Aggregate

River sand (Figure 2) had been used as fine aggregate for this project. The River sand was sieved through $4.75 \mathrm{~mm}$ size of sieve to remove the particles of size greater than $4.75 \mathrm{~mm}$. The aggregates were tested by IS code of 383- 1970 and the properties were mentioned in Table 2.

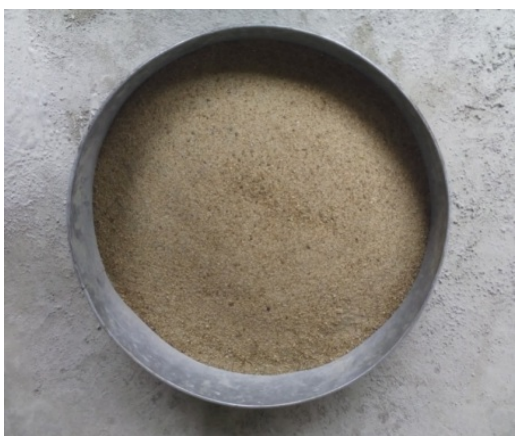

Figure 2 Fine Aggregate

Table 2 Properties of Fine aggregate (River Sand)

\begin{tabular}{|c|l|c|}
\hline S.No & \multicolumn{1}{|c|}{ Property } & Result \\
\hline 1. & $\begin{array}{l}\text { Fineness modulus } \\
\text { (IS 2386 - 1963) Part III }\end{array}$ & 2.34 \\
\hline 2. & Relative density & 2.6 \\
\hline
\end{tabular}




\section{Coarse Aggregate}

Aggregate (Figure 3) of size $10 \mathrm{~mm}$ is desirable for the paver block. Well graded rounded or cubical shape aggregates are generally used. In this project work aggregates of maximum size $10 \mathrm{~mm}$ has been used in order to increase the strength of the block. The properties of coarse aggregate were tested and mentioned in Table 3.

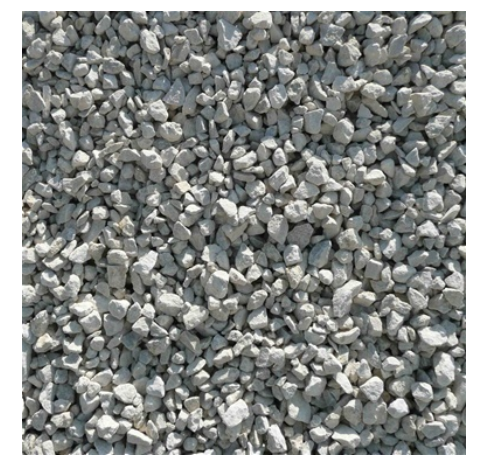

Figure 3 Coarse Aggregate

Table 3 Properties of Coarse aggregate

\begin{tabular}{|c|l|c|}
\hline S.No & \multicolumn{1}{|c|}{ Property } & Result \\
\hline 1. & $\begin{array}{l}\text { Fineness modulus } \\
\text { (IS 2386 - 1963) Part III }\end{array}$ & 6.65 \\
\hline 2. & Relative density & 2.86 \\
\hline 3. & Size & $10 \mathrm{~mm}$ \\
\hline
\end{tabular}

\section{Water}

Portable water having $\mathrm{pH}$ value of greater than 6 were used for this project as per the requirement of IS 456-2000 for mixing of concrete and curing process.

\section{Titanium dioxide}

Titanium dioxide or titanium is a naturally occurring oxide compound and it is generally used in toothpaste, paint, sunscreen, cosmetics, plastics, and other products. $\mathrm{TiO}_{2}$ is white in colour it doesn't produce any harmful effects and an inexpensive fine powder material. $\mathrm{TiO}_{2}$ powder (Figure 4) is used as pigments in ancient times. $\mathrm{TiO}_{2}$ is an important alloying agent with many metals and that alloy metals used to make aircrafts, spacecraft and missiles. It can be used as absorbent (absorbing UV light rays) in sunscreen without being consumed in the reaction. Titanium dioxide is inorganic substance, non-flammable, thermally stable, less soluble, and not produced hazardous effects. $\mathrm{TiO}_{2}$, available naturally in certain types of rocks and mineral sands. It is a most common element in upper surface of earth. 


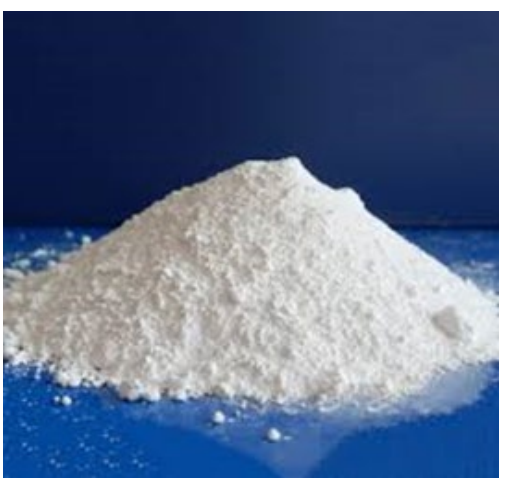

Figure 4 Titanium dioxide Powder

Table 4 Properties of Titanium dioxide $\left(\mathrm{TiO}_{2}\right)$

\begin{tabular}{|c|l|c|}
\hline S.No & \multicolumn{1}{|c|}{ Property } & Result \\
\hline 1. & Colour & White \\
\hline 2. & Odour & Nil \\
\hline 3. & Specific Gravity & 4.32 \\
\hline 4. & Density & $3.82 \mathrm{~g} / \mathrm{cc}$ \\
\hline
\end{tabular}

\section{Mix Proportion}

The mix design is formed by using IS code of 10262-2009 and $\mathrm{M}_{30}$ mix proportion value of 1:1.94:1.82 has been obtained. The quantity of materials required per $\mathrm{m}^{3}$ of concrete were found and mentioned in Table 4.

Table 5 Mix Proportion of Paver Block

\begin{tabular}{|c|l|c|}
\hline S.No & \multicolumn{1}{|c|}{ Material } & Quantity $\left(\mathbf{k g} / \mathbf{m}^{\mathbf{3}}\right)$ \\
\hline 1. & Cement (OPC 53grade) & 450 \\
\hline 2. & Fine aggregate (River sand) & 874.5 \\
\hline 3. & Coarse aggregate $(10 \mathrm{~mm})$ & 820.33 \\
\hline 4. & Water $(\mathrm{pH}>6)$ & 220.48 \\
\hline 5. & Water cement ratio & 0.45 \\
\hline
\end{tabular}

Methods of Application of $\mathrm{TiO}_{2}$ on the Paver Blocks

To absorb the pollutions like $\mathrm{CO}_{2}$ and $\mathrm{NO}_{2}$ we applied the titanium dioxide powder in three methods over the paver blocks. Those methods are

- $\mathrm{TiO}_{2}$ surface coating.

- $\mathrm{TiO}_{2}$ mixed with concrete.

- $\mathrm{TiO}_{2}$ curing process.

The paver block which is subjected to the application of $\mathrm{TiO}_{2}$ have the capability of reactingwith ultra violet radiations and hence has the capacity of absorbing the pollutions (Table 5). 
Table 6 Percentage of $\mathrm{TiO}_{2}$

\begin{tabular}{|c|c|c|}
\hline Method of application & $\begin{array}{c}\text { Amount of } \mathrm{TiO}_{2} \text { added into } \\
\text { cement }\end{array}$ & Amount of cement \\
\hline $\mathrm{TiO}_{2}$ surface coating & $\begin{array}{l}20 \% \text { (The percentage of } \mathrm{TiO}_{2} \\
\text { is fixed } 20 \% \text { by trial and } \\
\text { error method) }\end{array}$ & $80 \%$ \\
\hline $\begin{array}{l}\mathrm{TiO}_{2} \text { mixed with } \\
\text { concrete. }\end{array}$ & $\begin{array}{l}20 \% \text { (The percentage of } \mathrm{TiO}_{2} \\
\text { is fixed } 20 \% \text { by trial and } \\
\text { error method) }\end{array}$ & $80 \%$ \\
\hline $\mathrm{TiO}_{2}$ curing process & \multicolumn{2}{|c|}{$\begin{array}{l}\mathrm{TiO}_{2} \text { powder (is insoluble in water) is mixed with } \\
\text { water, approximately } 20 \mathrm{~g} \text { for } 1 \text { litre of water. }\end{array}$} \\
\hline
\end{tabular}

\section{Experimental program}

Dimensions of the Paver Block

Length $\quad: 225 \mathrm{~mm}$

Breadth $\quad: 150 \mathrm{~mm}$

Area of specimen $\quad: 33750 \mathrm{~mm}^{2}$

The paver block has four projections at corners we measured the area of the block by cutting two projections at one side of the block and filled inside the gaps on other side.
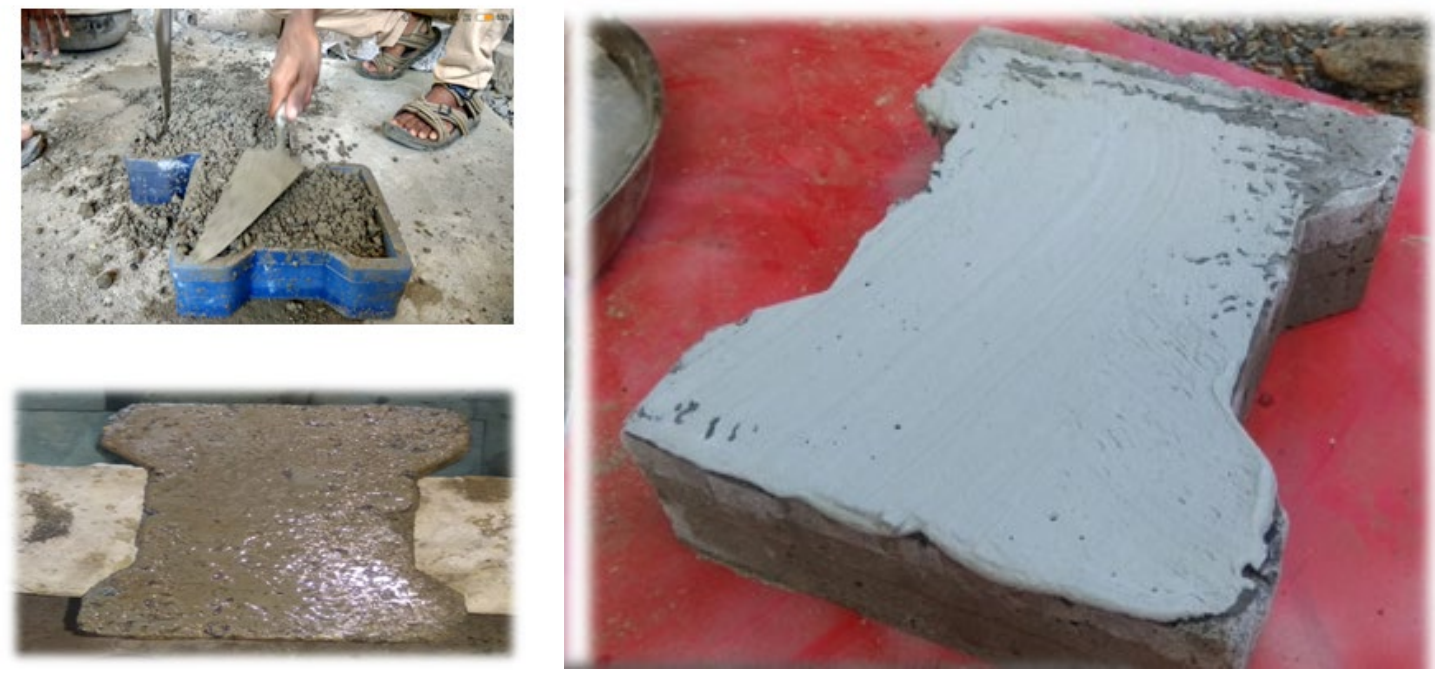

Figure 5 Paver blocks without and with $\mathrm{TiO}_{2}$

Compressive Strength of Concrete Paver Block

Compressive strength is the capability of a material to withstand compressive forces acting on that. Tensile strength is also the ability of a material to withstand forces trying to elongate (Table 6).

Pollution Absorption Test

With the use of $\mathrm{TiO}_{2}$ treated paver blocks corresponding pollution absorbing capacity will be found. The paver blocks absorb pollutions only if the surface is exposed to Ultraviolet radiations which were naturally obtained by the sunlight means of photocatalytic activity (Table 7). 


\section{Experimental Setup}

Air Tight Glass Chamber

The photo catalytic process of $\mathrm{TiO}_{2}$ is achieved under the condition of Ultraviolet radiation. Hence the transparent air tight glass chamber of size $22.86 \mathrm{~cm} \times 15.24 \mathrm{~cm} \mathrm{x} 15.24 \mathrm{~cm}$ is made in order to effectively absorb the vehicles pollutions.

The glass chamber is able to contian the $\mathrm{TiO}_{2}$ applied concrete paver block which helps in lowering the pollutions which was emitted by the vehicles.

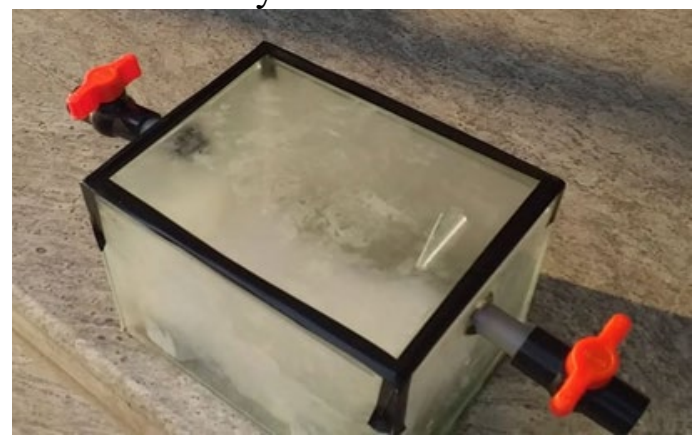

Figure 6 Air Tight Glass Chamber

Gas Analyser

Normal pollution analyser is used to test the pollution absorbing capacities of three types of $\mathrm{TiO}_{2}$ treated paver blocks. The analyser is capable of analysing the carbon monoxide, carbon dioxide, oxygen and hydro carbon by which the initial and final level of pollution content inside the air tight glass chamber was found.

Initially the pollution gas reading is obtained from the exhaust of the petrol engine powered vehicle, then that exhaust gas is allowed to fill the air tight glass chamber. After 30 minutes of exposure to Ultraviolet radiation final readings are noted down and found the reduction level of pollution gas.

\section{Test Results}

Compressive Strength Test Results of Paver Block

Table 6 shows the compressive strength test results of Paver Block at 7 days and 28 days. 
Table 7 Compressive Strength Test Results of Paver Blocks

\begin{tabular}{|c|c|c|c|c|}
\hline \multirow[t]{2}{*}{ Sample } & \multicolumn{2}{|c|}{$\begin{array}{l}\text { Compressive strength of } \\
\text { paver block at } 7 \text { days }\end{array}$} & \multicolumn{2}{|c|}{$\begin{array}{l}\text { Compressive strength of } \\
\text { paver block at } 28 \text { days }\end{array}$} \\
\hline & $\begin{array}{c}\text { Load in } \\
\qquad \mathbf{N}\end{array}$ & $\begin{array}{c}\text { Compressive } \\
\text { strength in } \\
\mathrm{N} / \mathrm{mm}^{2} \\
\end{array}$ & $\begin{array}{l}\text { Load in } \\
\qquad \mathbf{k N}\end{array}$ & $\begin{array}{c}\text { Compressive } \\
\text { strength in } \\
\mathrm{N} / \mathbf{m m}^{2} \\
\end{array}$ \\
\hline Sample 1 & 790 & 23.40 & 1080 & 32 \\
\hline Sample 2 & 780 & 23.11 & 1050 & 31.11 \\
\hline Sample 3 & 760 & 22.51 & 990 & 29.33 \\
\hline & Average & $23 \mathrm{~N} / \mathrm{mm}^{2}$ & Average & $30.81 \mathrm{~N} / \mathrm{mm}^{2}$ \\
\hline
\end{tabular}

Pollution Absorption Test

Table 8 Pollution Absorption Test

\begin{tabular}{|c|c|c|c|c|}
\hline \multirow[b]{2}{*}{ Types of gas } & \multirow{2}{*}{$\begin{array}{c}\text { Initial level } \\
\text { of } \\
\text { pollution }\end{array}$} & \multicolumn{3}{|c|}{$\begin{array}{l}\text { Final level of } \\
\text { pollution (ppm) }\end{array}$} \\
\hline & & $\begin{array}{c}\mathrm{TiO}_{2} \\
\text { surface } \\
\text { coating }\end{array}$ & $\begin{array}{c}\mathrm{TiO}_{2} \\
\text { mixed with } \\
\text { concrete }\end{array}$ & $\begin{array}{c}\mathrm{TiO}_{2} \text { curing } \\
\text { process }\end{array}$ \\
\hline Oxygen (\%) & 21.95 & 21.75 & 21.84 & 21.30 \\
\hline Hydro carbon (\%) & 633 & 105 & 98 & 234 \\
\hline Carbon dioxide $(\%)$ & 3.36 & 1.90 & 1.84 & 2.40 \\
\hline $\begin{array}{c}\text { Carbon monoxide } \\
\text { (ppm) }\end{array}$ & 2.063 & 1.99 & 2.03 & 2.53 \\
\hline
\end{tabular}

\section{Results and Discussion}

The compressive strength of $\mathrm{M}_{30}$ grade of concrete paver block at 7 days and 28 days was 23 $\mathrm{N} / \mathrm{mm}^{2}$ and $30.81 \mathrm{~N} / \mathrm{mm}^{2}$ respectively. The average percentage value of hydro carbon absorbed by $\mathrm{TiO}_{2}$ surface coating method was $83.41 \%$ and $\mathrm{TiO}_{2}$ mixed with concrete was $84.51 \% .43 .45 \%$ of carbon dioxide was absorbed by $\mathrm{TiO}_{2}$ surface coating method and $45.08 \%$ of carbon dioxide was absorbed by $\mathrm{TiO}_{2}$ mixed with concrete method. Both $\mathrm{TiO}_{2}$ surface coating and $\mathrm{TiO}_{2}$ mixed with concrete method has the slightly decreased variation in the oxygen level.

\section{Conclusion}

1. From the compression test results at 7 days and 28 days maximum strength was attained for mix proportion of $\mathrm{M}_{30}$ grade of concrete paver block.

2. As expected the $\mathrm{TiO}_{2}$ treated paver block effectively absorbed the pollutions emitted by the vehicle. 
3. Out of these three methods of $\mathrm{TiO}_{2}$ applied paver blocks, the $\mathrm{TiO}_{2}$ mixed with concrete performs more effective in absorbing the vehicles pollution.

4. Comparatively $\mathrm{TiO}_{2}$ mixed with concrete involves in the less alteration of oxygen and the percentage of hydro carbon level was highly absorbed by this method.

5. The percentage of carbon dioxide was absorbed efficiently by $\mathrm{TiO}_{2}$ mixed with concrete method.

6. Hence the Titanium dioxide mixed with concrete method was highly recommended and effective for the absorption atmospheric vehicle pollutions.

\section{References}

[1] Aniket Pisal, Akshay Jambhale, Sanket Gurav, Anandrao Jagtap, Rahul Mardhekar (2017), Eco Sensitivity Of Paving Block By Using Titanium Di-Oxide.

[2] Poonam Sharma, Ramesh Kumar Batra (2015), Cement concrete paver blocks for rural roads.

[3] Elia Boonen* and Anne Beeldens (2014), Recent Photocatalytic Applications for Air Purification in Belgium. https://doi.org/10.3390/coatings4030553

[4] Marwa M. Hassan, Heather Dylla, Louay N. Mohammad, and Tyson Rupnow (2012), Methods for the Application of Titanium Dioxide Coatings to ConcretePavement.

[5] Gian luca Guerrini, Anne Beeldens (2012), Environmental benefits of innovative photocatalytic cementitious road materials.

[6] Shihui Shen, Maria Burton, Bertram Jobson, and Liv Haselbach (2011), Pervious Concrete with Titanium Dioxide as a Photocatalyst Compound for a 1 Greener Urban Road Environment. https://doi.org/10.1016/j.conbuildmat.2012.04.097

[7] Lu Yang, Amer Hakki (2008), photocatalysis efficiency in concrete technology:The effect of photocatalysis placement.

[8] Anne Beeldens (2006), Environmental friendly concrete pavement blocks: air purification in the centre of Antwerp

[9] http://pubchem.ncbi.nlm.gov/compound/titanium_dioxide (Properties of titanium dioxide)

[10] http://pubchem.ncbi.nlm.gov/compound/zinc_oxide (Properties of zinc oxide)respectively 